\title{
Russian Far East in the System of Transportation Links between Europe and Asia
}

\author{
Petrunina Zhanna Valeryanovna \\ D. Phil. in History, Professor of the History and Archival Science Department \\ Komsomolsk-on-Amur State Technical University, Russia; E-mail: petrunina71@bk.ru
}

\section{Chibisova Olga Vladimirovna}

PhD in Cultural Studies, Associate Professor of Linguistics and Intercultural Communication Department Komsomolsk-on-Amur State Technical University, Russia; E-mail: olgachibisova@yandex.ru

\author{
Doi:10.5901/mjss.2015.v6n6s2p460
}

\begin{abstract}
The purpose of the study is to analyze the current state and prospects of Russian railways operating in the conditions of international integration, to identify the factors of mutual interest and possible risks of multilateral cooperation in transit using the potential of the Russian Federation. The outlets to the Baltic Sea and the Sea of Japan allow Russian government to suggest using Trans-Siberian and Baikal-Amur railways for Europe-Asia transport routes. The authors consider the most urgent problems of implementing the existing plans: the radical modernization of the railway infrastructure, the use of new technologies and the revision of the organization of transportation. To solve these problems the Russian leadership has offered and implemented various development programs. It also is trying to decide a point of attracting foreign capital. Special attention is paid to the cooperation between the Russian Federation and North Korea, South Korea and China. The implementation of joint projects will enhance regional cooperation and promote a safety zone for their participants. The authors conclude that the Trans-Siberian and Baikal-Amur railways retain their strategic importance as transportation links between Asia and Europe.
\end{abstract}

Keywords: transport routes, transit, regional development, international integration.

\section{Introduction}

The Russian Far East is the "gateway" in the Asia-Pacific region, which is developing dynamically in recent years. However, since the end of the twentieth century Far Eastern region of the country has experienced difficulties in social and economic development. The tight situation in which Russian Far Eastern territories found themselves, was caused by the economic decline in the whole country in the post-Soviet period, the collapse of the industrial base, the violation of economic ties and the loss of markets in the region, decline in living standards in the Far East of Russia and the outflow of people from this part of the country, the lack of investment in the regional economy.

Since the beginning of the XXI century the Russian leadership has been trying to resolve the crisis in the region, offering and implementing various development programs (eg, Federal special-purpose program "Economic and social development of the Far East and the Baikal region for the period till 2018"). In December 2013 in the annual Presidential Address to the Federal Assembly of the Russian Federation, the rise of Siberia and the Far East was determined as a national priority for the entire XXI century (Minvostokrazvitia, 2013). One of the ways to improve the economic and social life of the Russian Far East is the inclusion of the region in international cooperation with other countries of Asia-Pacific Region (APR) by modernizing and extending its transport and communications capabilities.

\section{Research Methods}

Traditional specific historical methods were used in the study.

The comparative historical method helped to identify common trends in the development of the transport system in the Far East in the XXI century and to define characteristic trends in the development of the transport sector in the Russian Far East at the present stage. The consistent consideration of changes in the Russian Far East transport infrastructure was conducted by means of historical-genetic method. This method allowed identifying causal relationships and patterns of development of the transport system in the post-Soviet era. The usage of a problem-chronological method made it possible to divide the research topic into a series of narrow and specific issues and consider each of 
them separately.

At the same time, systems approach combined all the components of the content into a single unit for them to be considered in dynamics and relationships. There was made a comprehensive analysis of the problems related to the policy implemented by the Russian government in the Russian Far East and foreign policy of the country in the AsiaPacific region. Through the method of source analysis and synthesis there were singled out main types of sources, including information about the development of the transport system in the Far East and the level of its compliance with the needs of the state.

\section{Russia and APEC Members}

In September, 2012 Vladivostok played host to the APEC Russia summit. One of priorities highlighted at the meeting was a development of the program directed at creating infallible transport chains which appearance and extension would considerably quicken and cheapen trade and economic interaction among Russia and countries of Asia and Europe (APEC, 2012). Today sales figures between Asia and Europe are more than $\$ 1$ trillion. At the average trade growth of $5 \%$ per year, it will double and become more than $\$ 2$ trillion by 2030. Goods are transported mainly in the direction from Asia to Europe, but in 10 years this trade flow is to become bidirectional. European manufacturers are interested in entering the China market which gradually turns into the world's largest consumer (Vorob'eva, 2012).

The fact that Russia has outlets to the Baltic Sea and the Sea of Japan allows its government to suggest using the railway tracks of the country for paving shorter and more profitable Europe-Asia transport routes. The usage of railway transportation through the territory of Russia by the Asia-Pacific countries for getting an access to European markets through the Baltic Sea is substantially more profitable and much safer than marine transportation through areas of East Africa. Russia offers to carry out freight traffic activity by the Trans-Siberian, where the rate of transportation almost $\$ 600$ cheaper than that by the southern transoceanic route across the Pacific, the Indian Ocean and the Suez Canal (llyukhov, 2008). Savings on transportation through the territory of Russia for foreign countries can be up to $\$ 370$ billion per year (Verkhoturov, 2012). Russia claims to receive 10\% of transit traffic between the countries of these regions (Vorob'eva, 2012). Besides, the implementation of the plans put forward will make it possible for domestic producers as well to increase trade volume and to enter the growing markets of Asia-Pacific countries, strengthening the transit potential of Russia's regions.

On June 17, 2008 the Russian government adopted a "Strategy for Development of Railway Transport of the Russian Federation until 2030". Determining the main directions of international activity and improving the competitiveness of rail transport, the developers of the document pointed to the special importance of Trans-Siberian Railway "in providing transport links between Europe and Asia, which has comprehensive potential facilities including the possibility of safe delivery of goods through the territory of Russia from the Pacific Ocean to the western borders for 11 days. They also assumed a growth of traffic flows on the Baikal-Amur Mainline in 7-10 times, especially near the ports of Khabarovsk Krai (Vanino, Sovetskaya Gavan)" (JSC "Russian Railways", 2008).

The reported proposals entail not only the expansion of mutually beneficial economic cooperation, but also an urgently radical modernization of the railway infrastructure, the use of new technologies and the revision of transportation organization in Russia. According to a number of foreign experts, Russia lags behind most APEC members because of "red tape and corruption, monopoly, numerous trade barriers, clumsy customs and confusing legal framework" (Vorob'eva and Khamraeva, 2012). All these factors require an immediate solution, because they are a significant obstacle to the expansion of economic contacts of Russia with APEC members.

\section{Current Situation in Russian Rail Infrastructure}

The existing rail infrastructure is unsuitable for Russia to commit itself to transporting goods from Asia to Europe. A bigger problem for including Russian railways in the system of international transportation presents a state of Trans-Siberian Railway and Baykal-Amur Mainline's (BAM) traffic-carrying capacity. Speaking at the plenary session of the Baikal Economic Forum, which was held in September 2011 in Irkutsk, chairman of En + Group O.V. Deripaska said that the capacity of the Trans-Siberian railway in the direction of the Far Eastern ports is less than $60 \mathrm{mln}$ tons per year, and the "total traffic-carrying capacity" of the railway crossings of Siberia and the Far East is only about 60 mln tons per year while a perspective demand is not less than 100 million tons (Deripaska, 2011).

In 2012, the entire capacity of the Trans-Siberian Railway amounted to $120 \mathrm{mln}$ tons per year, and the trafficcarrying capacity of BAM - only to $16 \mathrm{mln}$ tons (Verkhoturov, 2012). This is obviously not enough for a new level of economic cooperation between Russia and APEC. According to the president of Joint Stock Company "Russian 
Railways" V.I. Yakunin, "Transsiberian today is one of the busiest main lines in the world. Its capacity is practically exhausted" (Verkhoturov, 2012). It is important to remember that the current Trans-Siberian and BAM carry a significant amount of goods between the Russian regions. To increase the carrying capacity of the Trans-Siberian and BAM Russia developed a program "Vostochny Poligon" in 2013.

The Russian leadership attaches great importance to the solution of such important economic issues. There have been adopted and started state programs "Strategy of socio-economic development of the Far East and the Baikal region until 2020", "The strategy of socio-economic development of Siberia until 2020", "Transport Strategy to 2030", "Development strategy of rail transport until 2030". In the case of achieving the objectives set in the government programs to increase the BAM's capacity from 20 million to 50 million tons per year, an additional impetus will be given to developing ports in Primorsky and Khabarovsk Territories (Vostochny, Vanino, Sovetskaya Gavan), to expediting the implementation of a project "Vostochny - Nahodka"), and to developing actively the surrounding areas. Consequently, it will be possible to save the population of the Russian Far East, the number of which is now rapidly shrinking.

Deputy General Director of JSC "Institute for the Economy and Transport Development" S.N. Sharapov, in his speech at the World Economic Conference in the framework of the Baikal Economic Forum, held in September 2012 in Ulan-Ude, recorded the dynamics of freight traffic in the east of Russia. He linked this phenomenon with the development of new mineral deposits in the region and the construction of port facilities in Vanino-Sovetskaya Gavan transport nodal point and ports of Primorsky Territory. Significant investment is needed to fasten the pace of development. In his view, the needs for developing railway infrastructure in Siberia and the Far East until 2030 amount to 845.8 billion rubles, while JSC "Russian Railways" can spend only 430 billion rubles (Sharapov, 2012). At the same time, V.I. Yakunin said that in accordance with the general scheme of development of RRW network until 2020 it is necessary to invest 4.1 trillion rubles from 2012 to 2020. Out of this number the investment in the development of the Trans-Siberian and Baykal-Amur Mainline until 2020 will amount to 181 billion rubles and 737 billion rubles respectively, which together will amount to more than 114 billion rubles per year (Larionova, 2012).

Although the country should become a largest investor, the Russian leadership is trying to decide a point of attracting foreign capital. From this point of view, the project of connecting the Trans-Siberian and Trans-Korean Railways seems to be rather promising because investors in South Korea, businessmen and industrialists of the entire Asia-Pacific region are interested in its implementation. The integrated railway will speed up the economic cooperation between the two countries, strengthen the system of transit traffic between Asia and Europe, and create favorable conditions for the solution of the Korean question.

\section{The Project Hassan - Rajin}

The question about connecting the railways of the Korean Peninsula, Russia and European countries has become widely discussed since the beginning of the twenty-first century. In 2001, Russian President Vladimir Putin and DPRK leader Kim Jong II reached agreements, which reflected the desire of the parties to create a 14 thousand-kilometer-long rail transport corridor connecting the Korean Peninsula, Russia and European countries. Along with political decisions both sides began to undertake scientific and engineering surveys, aimed at restoring the Trans-Korean Railway and modernizing the North Korean port of Rajin. The vigorous activity of specialists and representatives of the Russian and DPRK authorities contributed to the signing of bilateral agreement on cooperation in the implementation of the pilot project "Hasan - Rajin" in April 2008. President of JSC "Russian Railways" Yakunin and Minister of Railways North Korea Jong Soo Gil signed protocol to start work. The project included the reconstruction of the railway Tumen - Rajin (54 km long), the construction of container-terminal in the port of Ragin, as well as subsequent maintenance of the infrastructure (RZDstroy, 2013). Under the agreement, in the special economic zone of the DPRK "Rason" the joint venture "RasonKonTrans" started its work in 2009. The JSC "Trading House Russian Railways" (70\% of the company's capital) represented Russia and the port of Rajin ( $30 \%$ of the company's capital) represented Korea. Estimated annual loading of this section of the railway was to reach 100 thousand containers.

In September 2013 the first phase of the reconstruction project of the Trans-Korean Railway on the site Hasan (RF) - Tumen (DPRK) - Rajin (DPRK) with the construction of a container terminal at the port of Rajin was over. In the course of the work "RasonKonTrans" lay a combined gauge $(1520 \mathrm{~mm}$ and $1435 \mathrm{~mm})$ and completed the reconstruction of 3 tunnels, 18 bridges and 12 culverts. All objects were put into operation. At first, the main freight was Russian coal. According to President of Russian Railways Vladimir Yakunin, the terminal in the port of Rajin is designed for "handling 4 million tons of coal a year" (Pitalev, 2013).

The project was also approved by the South Korean businessmen and politicians. According to representatives of South Korea, the project Hassan - Rajin has a special importance to the national interest of the country in the 
development of comprehensive relations with Russia (Choi, 2014). Russian President Vladimir Putin, on his visit to the Republic of Korea on November 13, 2013, expressed his interest in South Korea's participating in the project. The parties signed 8 agreements, including the "Memorandum of Understanding between the Ministry of transport of the Russian Federation and the Ministry of public areas and transport of the Republic of Korea on cooperation in the field of transport" and "Memorandum of Cooperation between JSC "Russian Railways", Company "POSCO", Railways Corporation of Korea and Company "Hyundai Merchant Marine Co.., Ltd." (Homepage of President of Russia, 2013).

In February 2014, South Korean experts made a working visit to the port of Rajin, where they had an opportunity to get acquainted with infrastructure. The tripartite consultations among heads of Russian, North Korean and South Korean railway administrations are of particular value for the further economic and political dialogue. If the Trans-Siberian and Trans-Korean Railways are connected, both North and South Korea will be able to satisfy their need for obtaining goods from the manufacturer and marketing products to interested consumers, they will gain access to Russian raw materials. In its turn, Russia will enter the markets of Northeast Asia and Southeast Asia.

\section{Silk Road Economic Belt Project}

Another promising project is the Silk Road Economic Belt which will join the Asia-Pacific and European countries using the rail network in Mongolia linked with the railways of China and the Russian Trans-Siberian Railway and the BaikalAmur Mainline. The idea of creating this zone as a new form of deepening cooperation between China and Russia was expressed by Xi Jinping on September 6, 2013 in Astana during his speech at Nazarbayev University.

Developing this program, the Chinese experts consider, firstly, advantageous geographical position of China, which shares a border with three countries Central Asia, and secondly, the world community's traditionally positive perception of the ancient Silk Road, thirdly, the possibility to extend economic cooperation not only in the countries of Central Asia, but also in the Caucasus and in the future, in the Middle East, and finally, the fact that China has economic and financial power and is able to multiply the amount of investment in major regional projects related to the modernization of infrastructure and the creation of an integrated transport network. It is also important that such measures meet the plans of Russia, which is interested both in enhancing regional cooperation, as well as in strengthening its Far Eastern borders.

The program formulated by Xi Jinping includes five areas of cooperation - the coordination of cooperation among states in the political sphere; the construction of an integrated railway network; the elimination of trade barriers and the improvement of the quality of economic transactions between the two countries; the transition to settlements in national currencies; the expansion of direct ties between the peoples of the region and the role of public diplomacy.

The Silk Road Economic Belt is definitely beneficial for Russia, because it means the implementation of transit potential and receipt of certain resources. "Russia has serious intentions to participate in the project of Silk Road's revival because it gets the economic development zones, on the basis of which other, more backward, areas will develop", says Andrei Ostrovsky, Deputy Director of the Institute for Far Eastern Studies (Mikhailov, 2014). The fact is that, for example, Tatarstan is very interested in the development of "Silk Road" because a significant part of the road goes through this region, and as part of this "Silk Road" it will become possible, in particular, to implement the project of a high-speed line "Moscow-Kazan." Russia is also interested in construction of a possible branch of the "Silk Road" - the planned highspeed rail length 7,000 kilometers which will link Moscow and Beijing, thereby reducing the travel time between the two cities from six or more days to about 33 hours. This project is important to Russia from another point of view: along the route there is created a safety zone which is provided by all project participants and beneficiaries.

On May 10, 2014 in Shanghai, CEO of "China Railway" Sheng Guangji and president of JSC "Russian Railways" Vladimir Yakunin signed a strategic cooperation agreement (Penzev, 2014). Under the agreement, it is scheduled to pay special attention to railway border crossing between Russia and China and the construction of railway infrastructure on the approaches to them, which should lead to an increase in carrying capacity of the railways. The parties also intend to optimize the conditions and technology of container traffic, in particular through the organization of regular trains on the transit routes "China - Russia - Europe". Besides, Russian and Chinese Railways plan to carry out the work necessary to shorten the delivery of goods in transit through the territories of their states, to improve security systems, to expand terminal and storage facilities on the main routes of transportation.

\section{Conclusion}

The Russian Far East railway infrastructure retains its strategic importance in the context of contemporary geopolitical changes in the Asia-Pacific region and the world at large. For Russia, Trans-Siberian and BAM are important for regional 
natural resources and infrastructure development of the entire Russian Far East. Railway Operation will create the necessary conditions for the preservation of the population and the improvement of the quality of life in the region.

There remains actual the question of expanding the opportunities for economic cooperation between Russia and north-eastern provinces of China, Mongolia, North Korea and South-East Asia. For achieving this goal it is essential for Russia to decide the issue of speeding up the modernization and expansion of Trans-Siberian and Baikal-Amur Railway capacities, the state of which is of little use in undertaking the freight volumes necessary for APR countries.

The increase in the Russian railway transit potential is determined by the willingness of the Russian leadership to coordinate plans for the development of these railways and transport infrastructure with Asian Pacific countries. This will make it possible to remove probable tension, competition and suspicion among the countries in matters of conjugating transport projects.

An important factor for accelerating the pace of Russian railways transit development is to attract private investment, which impetus is a favorable investment climate. The reluctance of private investors to invest in such longterm projects is due to the high level of corruption at all levels of government in Russia, the slowness in implementing the plans.

Thus, despite the difficulties, the Russian railways remain competitive and can take its rightful place in the international traffic between Asia and Europe, contribute to sustainable economic interaction of different parts of the world. Thus, the Trans-Siberian and BAM remain priority mainlines of modern Russia and retain their strategic importance. They can take their rightful place in the international traffic between Asia and Europe and contribute to sustainable economic interaction of different parts of the world.

\section{References}

APEC, (2012), APEC-2012 priorities. [Online] Available: http://rus.apec2012.ru/docs/about/priorities.html (January 10, 2015)

Choi, Hyun-june, (2014), Rajin-Hasan Project going ahead as a "special case". [Online] Available: http://english.hani.co.kr/arti/english_ edition/e_northkorea/623604.html (January 15, 2015)

Deripaska, Oleg, (2011), State Policy and strategy development of Siberia and the Far East. [Online] Available: http://www.deripaska. rulin_focus/detail.php?ELEMENT_ID=425\#.VOq-pCyf9Qc December 14, 2014)

Homepage of President of Russia, (2013). Documents signed following Russian-Korean talks. [Online] Available: http://news.kremlin.ru/ ref_notes/1563 (February 19, 2015)

llyukhov, Anatoly, (2008), The new railway crossing between Russia and China. [Online] Available: http://ria.ru/economy/200 30714/406568.html (December 19, 2014)

JSC "Russian Railways", (2008), Railway Transport Development Strategy of the Russian Federation until 2030. [Online] Available: http://doc.rzd.ru/doc/public/ru?id=3997\&layer_id=5104\&STRUCTURE_ID=704 (January 5, 2015)

Larionova, Tatiana, (2012), Transport is a skeleton of Russia. [Online] Available: http://www.transportrussia.ru/transportnaya-politika/ transport-eto-skelet-rossii.html (January 21, 2015)

Mikhailov, Andrei, (2014), The new Silk Road will connect Russia and China. [Online] Available: http://www.pravda.ru/economics/ rules/globalcooperation/02-05-2014/1206269-china-0/ (February 17, 2015)

Minvostokrazvitia, (2013), Vladimir Putin, in the annual Presidential Address to the Federal Assembly, called the rise of Siberia and the Far East a national priority for the entire XXI century. [Online] Available: http://minvostokrazvitia.ru/press-center/news_ minvostok/?ELEMENT_ID=1705 ( February 15, 2015)

Penzev, Constantine, (2014), By the end of Putin's visit to China. [Online] Available: http://globalconflict.ru/analytics/66337-k-itogamvizita-vladimira-putina-v-knr (January 11, 2015)

Pitalev, Ilya, (2013), Yakunin: railway section of Rajin-Khasan will revive the transit of goods through the Trans-Siberian. [Online] Available: http://ria.ru/economy/20130923/965097071.html (December 5, 2014)

RZDstroy, (2013), The modernization of the railway from Russia to North Korea. [Online] Available: http://www.rzdstroy.ru/press/ news/zavershena-modernizaciya-zheleznoj/ (February 19, 2015)

Sharapov, Sergey, (2012), Development of rail transport in Siberia and the Far East. Problem. Prospects. [Online] Available: http://www.gosbook.ru/node/62577 (February 6, 2015)

Verkhoturov, Dmitry, (2012), Transsiberian must carry a billion tons. [Online] Available: http://www.ru.journal-neo.com/node/11 (February $11,2015)$

Vorob'eva, Inga, (2012). In the countries of APEC they are unhappy with Russian Railways. [Online] Available: http://www.rbcdaily.ru/ politics/562949983921420 (February 9, 2015)

Vorob'eva, Inga and Khamraeva, Valeria, (2012), 'APEC experts recommend Russia to develop means of communication'. [Online] Available: http://www.rbcdaily.ru/politics/562949982915989 (February 2, 2015) 